\title{
Analysis on Halal Hotel Regulations in 5 Tourism Spots in Order to Increase Halal Tourism in Indonesia
}

\author{
Gemala Dewi ${ }^{1}$, Maudyna ${ }^{2}$, Fahrul Fauzi ${ }^{3}$, Velladia Zahra Taqiya ${ }^{4}$, Erizka Permatasari $^{5}$, \\ Andini Naulina Rahajeng ${ }^{6}$ \\ \{maudyna@ui.ac.id ${ }^{2}$ \}
}

Faculty of Law, Universitas Indonesia, 16424, Indonesia ${ }^{1,2,3,4,5,6}$

\begin{abstract}
To develop Indonesian halal tourism achievement, Majelis Ulama Indonesia issued Fatwa to standardize the halal tourism based on sharia principle. However, this only give the general principle. Hotel being one of the important aspect to the tourism has the need to have a regulation to standardize the technical aspect. To find out the results of each advantage and disadvantage of hotel halal tourism regulations in the 5 regions order give recommendation to regulate halal hotel in Indonesia. This research employs an empirical and comparative approach by analyzing each of the selected region's regulations and the data obtained from the literature study and by interviewing sources and experts. Halal hotel regulations in various regions of Indonesia have their own classifications and standards. It is not clear whether the halal hotel referred to in various regulations is a sharia hotel or a Muslim friendly hotel. Also, there is no technical aspect standardization. This study would give recommendations to hotel halal regulation in order to protect consumer religious rights on tourism. This study relates to consumer protection aspect, tourism aspect, and law aspect, especially in Islamic Law and Public Governance.
\end{abstract}

Keywords: Islamic Law, Halal Hotel, Halal Tourism, Consumer Protection.

\section{Introduction}

Currently, the world's Muslim population is 1.8 billion of the world's population, which has reached 7.7 billion. [1] Muslims spent US \$2.2 trillion in 2018 across the food, pharmaceutical, and lifestyle sectors influenced by ethics inspired by Islamic beliefs, and this is expected to reach US $\$ 3.2$ trillion by 2024. [1] The halal lifestyle currently developing in the global world consists of halal food, Islamic finance, Muslim-friendly travel, modest fashion, halal pharmaceutical, halal cosmetics, and halal media and recreation. Expenditures for Indonesian Muslims for a halal lifestyle can be seen in the Table 1.

Indonesia has more than 17000 islands, more than 300 ethnic groups, 742 languages; there are world heritage sites, 51 national parks, and the world's 3rd largest biodiversity. Tourism is a strategic sector in contributing to the economy in Indonesia besides the oil and gas sector. The tourism industry is large and is seen as a sector that accelerates economic growth [2]. Therefore, the role of the national tourism sector is increasingly important in line with the development and contribution provided by the tourism sector through foreign exchange earnings, regional income, regional development, as well as in the absorption of investment and labor as well as business development spread across various regions throughout Indonesia [3].

Indonesia also has a majority of the population who adhere to the Muslim religion. This makes the halal tourism industry also growing. The government is taking serious steps towards 
this. The development of Indonesian halal tourism has become one of the Ministry of Tourism's priority programs since 2014. To support this program, the government has formed a Team for the Acceleration of Halal Tourism Development. After five years running, in 2019, Indonesia was ranked first as a world halal tourist destination in the GMTI version or the 2019 Global Muslim Travel Index at the International level. According to The Global Islamic Economy Indicator, Indonesia has increased substantially from the tenth position in 2018 to fifth place this year, supported by the strength of initiatives to boost economic growth.

Table 1. State of the Global Islamic Economy 2019-2020

\begin{tabular}{lrrr}
\hline Halal Lifestyle Sector & Indonesian Muslims & Global Muslims & $\begin{array}{r}\text { Market } \\
\text { Share }\end{array}$ \\
\hline Food & US\$ 173 Billion & US\$ 1,37 Trillion & $5,10 \%$ \\
Sharia Finance & US\$ 86 Billion & US\$ 2,52 Trillion & $3,50 \%$ \\
Mode & US\$ 21 Billion & US\$ 283 Billion & $4,80 \%$ \\
Media and Recreation & US\$ 10 Billion & US\$ 220 Billion & $5,30 \%$ \\
Muslim Friendly Travel & US\$ 11 Billion & US\$ 189 Billion & $6,80 \%$ \\
Pharmacy & US\$ 5 Billion & US\$ 92 Billion & $5,70 \%$ \\
Cosmetics & US\$ 4 Billion & US\$ 64 Billion & $4,90 \%$ \\
\hline
\end{tabular}

The increase in Indonesia's ranking as a halal tourist destination cannot be separated from regional participation that is a favorite destination for halal tourism, such as West Nusa Tenggara Province, Riau Province, Nanggroe Aceh Darussalam Province, West Sumatra Province, DKI Jakarta Province, West Java Province, Central Java Province, Province Yogyakarta, East Java Province, and South Sulawesi Province. In fact, West Nusa Tenggara won two World Halal Travel Awards (WHTA) 2015 in World Best Halal Tourism Destination and World Best Halal Honeymoon Destination. This is because Lombok has relatively complete facilities to support halal tourism. In terms of food, Lombok has 60 halal-certified halal restaurants and 1,076 restaurants that claim to be halal even though they have not been certified by the Halal Product Guarantee Agency (BPJPH). As for other support, Lombok already has 8,456 mosques and 60 hotels that claim to be halal certified. Meanwhile, there are 510 hotels and 3,683 restaurants that claim to be halal certified in Jakarta and have 7,795 mosques [4].

Indonesia's achievements in the halal tourism sector have the potential to continue to be improved. In its development, the Government of Indonesia through the Minister of Tourism and Creative Economy Regulation Number 2 of 2014 concerning Guidelines for Implementation of Sharia Hotels. Sharia, referred to here, is Islamic law principles as regulated by fatwas and/or has been approved by the Indonesian Ulema Council (MUI) [5]. Although Permenparekraf 2/2014 was revoked in its development, the government's enthusiasm in supporting the realization of halal tourism can still be seen by enacting Law Number 33 of 2014 concerning Halal Product Guarantee, which requires all products to enter, circulate, and be traded in Indonesia to be certified halal [6]. The Government made this reaffirmation through Law Number 11 of 2020 concerning Job Creation, which then made it easier for MSMEs to carry out their obligations to provide halal certification for the products they sold [7].

Thus, in the case of culinary tourism, namely food and beverages in Indonesia, halal certification is carried out by the Halal Product Management Guarantee Agency [6] based on the halal determination from MUI [7], which is marked with an official halal logo on food and beverage packaging. An inspection is carried out by The Food and Drug Supervisory Agency (BPOM) so that there is a clear difference between halal and non-halal food. Indonesia is synergizing with many parties to develop halal tourism, for example, the Ministry of Tourism, 
which collaborates with the National Sharia Council (DSN), the Indonesian Ulema Council (MUI), and the Business Certification Institute (LSU) [8].

In supporting the development of halal tourism, the Indonesian Ulema Council issued a standardization in its fatwa on Islamic tourism guidelines. These guidelines regulate tourism to be held in sharia, which must comply with the principles of avoiding idolatry, immorality, and keeping away from useless and creating benefits both materially and spiritually.

Halal hotels are one of the areas that can be developed to support halal tourism in Indonesia. A study conducted by Jattanasan and Jaroenwisan [9] revealed that the sharia hotel features consist of the following 16 features: no alcohol, only halal food, conservative television service, majority of the staff are Muslim, Al-Quran \& prayer books are available in every room, recreational facilities separate for men \& women, there is a Qibla direction in each room, no entertainment such as night clubs, beds \& toilets should not be placed facing the Qibla direction, art objects in the hotel do not depict the human form, there is a bidet in the bathroom, entertainment is Accordingly, hotels that are financed by Islamic finance and hotels must follow the principle of zakat.

Halal hotels or many are also referred to as sharia hotels, have developed in recent years. The emergence of halal hotels in Indonesia is one-way companies can compete with existing conventional hotels. By relying on sharia principles, it is hoped that halal hotels will attract the attention of tourists, especially Muslim tourists. Muslim tourists are expected to feel at home staying in a shrouded place in security, cleanliness, and sanctity. There is also no need to worry about praying because the Qibla direction has been given, the bathroom with holy water purifies, the food provided is halal food marked with an MUI certificate, even services from the hotel prioritize politeness, and no discotheques can cause side effects [10]. A halal hotel that is very important to support the halal tourism industry needs to be supported and considered by the government as policymakers and business actors. So, it is essential to find a special formulation to regulate halal hotels in Indonesia.

This paper will compare several halal tourism regulations, especially those regulating halal hotels in halal tourist choice destinations in Indonesia, and comparing them with halal tourism arrangements in Malaysia and Turkey developed earlier. This comparison is carried out to find the advantages and disadvantages of each halal hotel arrangement in Indonesia and find a strong formulation to make a halal hotel regulation in Indonesia

\section{Method}

The research method used in producing this paper is the normative legal research method. Legal research is a scientific activity based on methods, systematics, and certain thoughts that aim to study one or more specific legal phenomena by analyzing them. In normative legal research, researchers use library materials or secondary data consisting of primary legal materials, secondary legal materials, and tertiary legal materials [11] which regulate or discuss halal tourism or halal tourism, and good halal hotels, namely the Halal Tourism Regulation in each province, the MUI Fatwa on Halal Tourism, and other laws and regulations that regulate it. The data analysis technique used in this research is the qualitative data analysis technique. Efforts are made by working with data, organizing data, sorting it into manageable units, synthesizing, looking for and finding patterns, finding something important to study, and deciding what to write for others to read [12]. 


\section{Results and Discussion}

\subsection{Terminology of Halal Hotels and Sharia Hotels}

Halal term in Islam is known for the term whether or not to consume an item. 'Halal' used for products, for example are foods and cosmetics. Etymologically halal means it is permissible, free or detached [13]. Whereas in terms of halal is the law of an act or goods for consumption that is permitted by the Shari'a. For that is the term halal how to obtain it and halal substances. There are also those who say that halal is something that is permitted by the Shari'a to be done, used or attempted.

In its development, the etymology of 'halal' is not only used to refer to food or products that are consumed but more broadly, it can be used to refer to tours and hotels that comply with sharia principles. In fact, the term "halal" has now become a marketing trend that businesses use to attract Muslim consumers.

Islamic hotels are divided into two categories, namely, hilal one and two hilal sharia hotels [14]. Hafizuddin Ahmad, the Sharia Supervisory Board of Hotel Sofyan, added that in the formulation of the Permenparekraf, the three hilal categories were the highest level of Islamic hotels. In this case, the hotel has met all sharia principles, both in hotel management, facilities, restaurants, and financial management.

To be able to become a sharia hotel, hotels must go through the stages of the Sharia Hotel Business Certification, which is a process of giving certificates by the MUI DSN to the hotel business through audits to assess the suitability of products, services, and hotel business management with the criteria for Sharia Hotel Business. However, because the Permenparekraf was revoked in 2016, currently, the regulations regarding sharia hotels are no longer regulated nationally. These regulations are still regulated in regional level regulations, one of which is in West Nusa Tenggara Governor Regulation Number 51 of 2015 concerning Halal Tourism [15].

\subsection{Regulation of Halal Hotels in Indonesian Halal Tourist Destination Cities}

Halal hotels as accommodation are important things that need to be considered in the context of halal tourism. So, it needs to be regulated in a regulation. The authors in Table 2 have compared several local regulations in Indonesia regarding halal tourism which regulates halal hotels.

Table 2. Comparison of Halal Hotel Arrangements in 5 Provinces

\begin{tabular}{|c|c|c|c|c|c|}
\hline Indicator & West Nusa Tenggara & West Sumatra & $\begin{array}{l}\text { Nanggroe Aceh } \\
\text { Darussalam }\end{array}$ & Riau & DKI Jakarta \\
\hline $\begin{array}{l}\text { Legal } \\
\text { Instruments }\end{array}$ & $\begin{array}{l}\text { West Nusa Tenggara } \\
\text { Governor Regulation } \\
\text { Number } 51 \text { of } 2015 \\
\text { concerning Halal } \\
\text { Tourism }\end{array}$ & $\begin{array}{l}\text { West Sumatra } \\
\text { Provincial } \\
\text { Regulation } \\
\text { Number } 1 \text { of } \\
2020 \\
\text { concerning the } \\
\text { Implementatio } \\
\text { n of Halal } \\
\text { Tourism }\end{array}$ & $\begin{array}{l}\text { Qanun Aceh } \\
\text { Number } 8 \text { of } \\
2013 \text { concerning } \\
\text { Tourism. } \\
\text { Halal tourism } \\
\text { arrangements are } \\
\text { more specifically } \\
\text { regulated in } \\
\text { city/regency } \\
\text { regulations. }\end{array}$ & $\begin{array}{l}\text { Riau Governor } \\
\text { Regulation } \\
\text { Number } 18 \\
\text { Concerning Halal } \\
\text { Tourism. }\end{array}$ & $\begin{array}{l}\text { Governor of } \\
\text { DKI Jakarta } \\
\text { Regulation } \\
\text { No. } 158 \text { of } \\
2013 \\
\text { concerning } \\
\text { Procedures } \\
\text { for Halal } \\
\text { Certification } \\
\text { for } \\
\text { Restaurants } \\
\text { and Non- } \\
\text { Restaurants }\end{array}$ \\
\hline
\end{tabular}




\begin{tabular}{|c|c|c|c|c|c|}
\hline $\begin{array}{l}\text { Halal Hotel } \\
\text { Arrangemen } \\
\text { t }\end{array}$ & Quite complete & Do not specify & $\begin{array}{l}\text { Not specifically } \\
\text { mentioning a } \\
\text { 'halal hotel', but } \\
\text { still referring to } \\
\text { sharia values }\end{array}$ & $\begin{array}{l}\text { Arranged briefly } \\
\text { regarding } \\
\text { accommodation } \\
\text { standards } \\
\text { according to } \\
\text { sharia standards }\end{array}$ & $\begin{array}{l}\text { Regulations } \\
\text { regarding } \\
\text { halal hotels in } \\
\text { DKI Jakarta } \\
\text { are still in the } \\
\text { process of } \\
\text { being } \\
\text { established. }\end{array}$ \\
\hline Substance & $\begin{array}{l}\text { Standardization of } \\
\text { halal hotels: } \\
\text { a. suitable facilities } \\
\text { for purification } \\
\text { are available; } \\
\text { b. available facilities } \\
\text { that make it easy } \\
\text { to worship; } \\
\text { c. available halal } \\
\text { food and drinks; } \\
\text { d. facilities and an } \\
\text { atmosphere that is } \\
\text { safe, comfortable, } \\
\text { and conducive to } \\
\text { families and } \\
\text { businesses; } \\
\text { maintained } \\
\text { sanitation and } \\
\text { environmental } \\
\text { hygiene. }\end{array}$ & $\begin{array}{l}\text { Only explains } \\
\text { the criteria for } \\
\text { accommodatio } \\
\mathrm{n} \text { businesses } \\
\text { that are } \\
\text { included in the } \\
\text { halal tourism } \\
\text { business }\end{array}$ & $\begin{array}{l}\text { The obligations } \\
\text { of star hotel } \\
\text { managers: } \\
\text { a. maintain and } \\
\text { prevent the use } \\
\text { of star hotels } \\
\text { from activities } \\
\text { that can } \\
\text { interfere with } \\
\text { security and } \\
\text { order general } \\
\text { and violates } \\
\text { Islamic law } \\
\text { b.maintain } \\
\text { hygienic and } \\
\text { sanitation in } \\
\text { hotels and the } \\
\text { yard } \\
\text { environment }\end{array}$ & $\begin{array}{l}\text { a. } \begin{array}{l}\text { There are } \\
\text { proper }\end{array} \\
\text { facilities for } \\
\text { purification } \\
\text { b. Some } \\
\text { facilities } \\
\text { make it easy } \\
\text { to pray } \\
\text { c. Halal food } \\
\text { and drinks are } \\
\text { available } \\
\text { d. facilities and } \\
\text { atmosphere } \\
\text { that is safe, } \\
\text { comfortable, } \\
\text { and } \\
\text { conducive to } \\
\text { family and } \\
\text { business; and } \\
\text { e. maintained } \\
\text { sanitation and } \\
\text { environmenta } \\
1 \text { hygiene }\end{array}$ & $\begin{array}{l}\text { Meanwhile, } \\
\text { the regulation } \\
\text { regarding } \\
\text { halal } \\
\text { certification } \\
\text { that can help } \\
\text { hotels is in } \\
\text { certifying } \\
\text { their } \\
\text { restaurant } \\
\text { services. }\end{array}$ \\
\hline
\end{tabular}

\subsection{Evaluation of Domestic Halal Hotel Arrangements}

Evaluation of Domestic Halal Hotel Arrangements lacks a detailed explanation of the accommodation business in halal hotels in Indonesia. This results in different standards of halal hotels. So, a certified sharia hotel is needed to support the criteria and standards of sharia hotels. Therefore, it is necessary to have regulations governing Islamic hotels' criteria and standards as a reference for these Islamic hotels.

\section{Conclusion}

Indonesian halal tourism has a good reputation in global circles. This will have a good impact on improving the nation's economy. In general, the Indonesian government has realized the potential for the development of halal tourism in Indonesia. This is evidenced by the provision of various arrangements that support the implementation of halal tourism, both at the national and regional levels, especially in terms of halal accommodation. The replacement arrangements regarding the guidelines for operating halal hotels that have been revoked need to be announced immediately, considering that halal accommodation is an important aspect to support halal tourism in Indonesia. So, from this research, halal tourism requires regulations regarding certified sharia hotels to support the criteria and standards of sharia hotels that provide 
safety and comfort for the whole family when traveling. This is because security, health, beauty, and hospitality are the concepts of halal tourism and halal hotels following Islamic law.

\section{Acknowledgement}

The writing of this article was funded by a research grant from the PUTI Proceedings of the University of Indonesia for the 2020 fiscal year based on a contract addendum dated November 6, 2020, Number NKB-3846/UN2.RST/HKP.05.00/2020. The author would also like to thank related speakers, including Rianto Sofyan, B.S.E.E., MBA. As Chairman of the Indonesian Halal Tourism Association, Hafizuddin Ahmad, as the Sharia Supervisory Board of Sofyan Hotel, Muhammad Quraisy, Ph.D., as a representative of the National Committee for Sharia Economics and Finance (KNEKS), and H. Lalu Moh. Faozal, S.Sos., M.Si, as the Head of the West Nusa Tenggara Provincial Tourism Office.

\section{References}

[1] Dinar Standard, "State of the Global Islamic Economy Report," Dinar Standard, 2020.

[2] H. Ferdiansyah and C. Endyana, "Pengembangan Pariwisata Halal di Indonesia melalui Smart Tourism," Journal of Sustainable Tourism Research, vol. 2, no. 1, p. 30, 2020.

[3] Lembaga Penyelidikan Ekonomi dan Masyarakat Fakultas Ekonomi dan Bisnis Universitas Indonesia, "Laporan Akhir Kajian Dampak Sektor Pariwisata Terhadap Perekonomian Indonesia," Lembaga Penyelidikan Ekonomi dan Masyarakat Fakultas Ekonomi dan Bisnis Universitas Indonesia.

[4] R. Setiawan, "10 Destinasi yang Jadikan RI Juara Wisata Halal," Detik.com, 16 April 2019. [Online]. Available: https://travel.detik.com/travel-news/d-4513215/10-destinasi-yang-jadikan-ri-juarawisata-halal. [Accessed 12 October 2020].

[5] Kementerian Pariwisata, "Laporan Akhir Kajian Pengembangan Wisata Syariah," Kementerian Pariwisata, Jakarta, 2015.

[6] Indonesia, "Undang-Undang Tentang Jaminan Produk Halal, UU No. 33 tahun 2014, LN No. 295 tahun 2014, TLN No. 5604," 2014.

[7] Indonesia, "Undang-Undang tentang Cipta Kerja, UU Nomor 11 tahun 2020, LN No. 245 tahun 2020, TLN No. 6573".

[8] A. Jaelani, "Halal Tourism Industry in Indonesia: Potential and Prospect," MPRA Paper, p. No. 76237, 2017.

[9] A. Jurattanasan and K. Jaroenwisan, "The attribution of shariah compliant hotel in Muslim countries," Review of Integrative Business and Economics Research, vol. 3, p. 39, 2014.

[10] M. Mujahidin, "Sharia hotels in Indonesia: Concept and potential analysis," Munich Personal RePEc Archieve, vol. 90819, p. 5, 2018.

[11] S. Soekanto, Pengantar Penelitian Hukum, Jakarta: Penerbit Universitas Indonesia, 1986.

[12] L. J. Moleong, Metodologi Penelitian Kualitatif, Bandung: Remaja Rosdakarya, 2017.

[13] M. Ali, "Konsep Makanan Halal dalam Tinjauan Syariah dan Tanggung Jawab Produk atas Produsen Industri Halal," Jurnal Ahkam, vol. 16, no. 2, 2016.

[14] Menteri Pariwisata dan Ekonomi Kreatif Republik Indonesia, "Peraturan Menteri Pariwisata dan Ekonomi Kreatif Nomor 2 Tahun 2014 tentang Pedoman Penyelenggaraan Usaha Hotel Syariah".

[15] Fibrianti, N. (2020). Penyelenggaraan Perlindungan Konsumen: Sinergi Negara, Pelaku Usaha dan Konsumen. Borobudur Law Review, 2(2), 90-101. 